\title{
Are women with breast cancer more likely to follow dietary recommendations and have sufficient vitamin $A$ intake compared to healthy controls?
}

\section{¿Es posible que las mujeres con cáncer de mama sigan las recomendaciones dietéticas y tengan una ingesta suficiente de vitamina $A$ en comparación con las mujeres controles?}

\begin{abstract}
To evaluate differences in dietary habits among women with breast cancer versus healthy controls. We conducted a case-control study with 160 women with and without cancer, pairing 1:1. Socio-demographic variables and food consumption were investigated through three food recalls, which was corrected for energy variation using the residual method. Data analysis was performed using KolmogorovSmirnov, Student's t, Mann-Whitney/Wilcoxon Two-Sample tests and calculating odds ratios with level of significance of $p<0.05$. The majority $(87.5 \%)$ of women with breast cancer did not follow dietary recommendations. Women with breast cancer (cases) had higher odds of not following dietary recommendations compared to controls $(O R=3.37$, $95 \% \mathrm{Cl}=1.50-7.58, p=0.004)$. Regarding consumption of micro and macronutrients, breast cancer patients had increased odds of insufficient vitamin A intake compared to controls $(O R=2.46,95 \% \mathrm{Cl}=1.19-5.05, p<0.01)$. The results suggest the women with breast cancer are more likely to not follow dietary recommendation and have insufficient consumption of vitamin A compared to women without breast cancer.

Keywords: Breast Neoplasms; Diet; Nutrients; Vitamin A; Women.
\end{abstract}

\section{RESUMEN}

Evaluar diferencias en los hábitos alimentarios de mujeres con cáncer de mama y mujeres normales. Estudio de casos y controles con 160 mujeres con y sin cáncer y emparejamiento de 1:1. Se investigaron las variables sociodemográficas y el consumo de alimentos mediante tres encuestas alimentarias, sometidas a la corrección de la variación de energía por el método residual. El análisis fueran realizados por Kolmogorov-Smirnov, t-Student, Mann-Whitney/ Wilcoxon y Odds Ratio con nivel de significación: $p<0,05$. La mayoría de las mujeres con cáncer de mama $(87,5 \%)$ no siguió las recomendaciones dietéticas. Las mujeres con cáncer de mama tuvieron un mayor riesgo de no seguir las recomendaciones dietéticas en comparación con los controles 3.37 (IC 95\%= 1.50-7.58, $p=0.004$ ). Con respecto al consumo de micro y macronutrientes, las mujeres con
Priscylla Rodrigues $\mathrm{V}^{1 *}$, Karine Anusca $\mathrm{M}^{1,2}$, Larissa Vaz $\mathrm{G}^{2}$, Elisa Silva Correia ${ }^{1}$, Marina de Sá $A^{1}$, Jéssika Martins $S^{1}$, Jordana Marques $\mathrm{GM}^{2}$.

1. Nutrition College. Federal University of Goiás. Rua 227, Qd 68, S/N Setor Leste Universitário, Goiânia, Goiás, Brazil. 2. Advanced Center for Breast Diagnosis of Hospital das Clínicas at the Federal University of Goiânia, Brazil (CORA / HC-UFG).

*Corresponding author: Priscylla Rodrigues V. Rua 227, Qd 68, S/N - Setor Leste Universitário, Goiânia, Goiás, Brazil. CEP: 74605-080. Phone: +55 62982778919 . E-mail: priscyllarvilella@gmail.com

Este trabajo fue recibido el 28 de agosto de 2018. Aceptado con modificaciones: 13 de marzo de 2019 . Aceptado para ser publicado: 04 de agosto de 2019.

cáncer de mama tuvieron un mayor riesgo de ingesta insuficiente de vitamina A en comparación con los controles $(O R=2.46$, IC 95\% = 1.19-5.05, $p<0.01)$. Los resultados sugieren que las mujeres con cáncer de mama tienen más riesgo de no seguir las recomendaciones dietéticas con un consumo insuficiente de vitamina A en comparación con las mujeres sin cáncer de mama.

Palabras clave: Dieta; Mujeres; Neoplasmas de la mama; Nutriente; Vitamina A.

\section{INTRODUCTION}

Breast cancer is the second most frequent cancer worldwide and the most prevalent among women. There is an estimated 59,700 new cases of breast cancer in Brazil; 
1,670 in the state of Goiás and 560 in the city of Goiânia for each year of the biennium 2018-2019'. In addition, the disease is the leading cause of cancer death, presenting high incidence and mortality, poor quality of life and high direct and indirect costs, becoming a public health problem²

Breast cancer etiology is multifactorial and includes non-modifiable factors, such as age and family history of breast cancer and modifiable factors: nulliparity, absence of breastfeeding, the use of postmenopausal hormone therapy, physical inactivity, weight gain, alcohol consumption, and nutrition ${ }^{3,4}$. The American Cancer Society addresses factors related to the diet to reduce breast cancer risk, emphasizing plant-based foods. A diet pattern that is rich in fruits and vegetables promotes the adequate consumption of micronutrients ${ }^{4}$.

Nutritional and dietary factors are identified as possible protective factors to cancer development, since they may influence the expression of key genes in mammary carcinogenesis. They can silence, activate or modify, thus modulating hormonal axes and influencing the growth and proliferation among specific cellular populations ${ }^{5,6}$. Among the dietary components which may act blocking breast carcinogenesis, fiber, vitamins, minerals, phytochemicals and polyunsaturated fatty acids, omega- 3 fatty acid and conjugated linoleic acid, present in some fruits, vegetables, eggs and milk, can be highlighted?

Vitamin A and its derivatives are classified as antioxidants and perform an important role in biologic processes such as the control of cell differentiation, proliferation and apoptosis therefore it may act to inhibit malignant neoplasms ${ }^{8}$. Also, vitamin A may play a role in breast cancer development since studies have shown a correlation between the plasma concentration of carotenoids and the risk decrease of breast cancer development and mortality ${ }^{9,10}$. Thus, supporting the recommendation to consume plant-based foods since the source of carotenoids in diet are fruits and vegetables ${ }^{4,10}$. However, studies remain inconclusive $e^{3,4,5,6,7}$.

We evaluated associations between nutritional profile, micronutrient and macronutrient intake among women with and without breast cancer who attended a federal public referral center.

\section{MATERIALS AND METHODS}

We conducted a case-control study that used a convenience sample from the cohort project entitled "Impact of chemotherapy treatment on body composition, lipid and glycemic profiles among women with breast cancer". The study was approved by the Research Ethics Committee of the Federal University of Goiás (CEP/UFG) under the report number 751.387 on August 2014. All the patients who agreed to participate in the study signed the Free and Informed Consent Form.

The study sample was divided into 80 women newly diagnosed with breast cancer (cases) who attended the Breast Diagnostic Reference Center at the Hospital das Clínicas at the Federal University of Goiás (CORA/HC-UFG), and 80 women without malignancy changes in the breast (controls). The volunteers were over 30 years of age, matched by age (quinquennium). We excluded women diagnosed with breast cancer recurrence and/or in treatment with palliative chemotherapy; with amputations or orthopedic problems that could compromise nutritional status, with psychiatric or neurological problems and presence of another neoplasia.

Data was collected through a pre-tested and standardized questionnaire. Sociodemographic variables investigated were age (in years), skin color (white/yellow and black/brown), marital status (with and without partner), city (Goiânia and outside the capital) and years of study.

The 24-hour dietary recalls were conducted on three non-consecutive days of the week; one of which had to a weekend $^{11}$. This was done for the characterization of energy, macro and micro-nutrient food intake. The first questionnaire was completed in person and the last two were done through a telephone interview. The participants were asked about what kinds of food they ate and the amount that they consumed per meal. From the questionnaires we calculated macro and micronutrients using AVANUTRI software.

The results obtained for macronutrients were compared to the minimum and maximum intake amounts stipulated by the World Health Organization (WHO) and the United Nations Fund for Food and Agriculture $(\mathrm{FAO})^{12}$. The cut-off point for energy consumption used was $1750 \mathrm{Kcal} /$ day, which was based on the average intake among women diagnosed with breast cancer from a study conducted in Brazil ${ }^{13}$. As stipulated by the $\mathrm{WHO}$, carbohydrates should make up $55-75 \%$, proteins $10-15 \%$ and lipids $15-30 \%$; these values were adopted as the standard for the study ${ }^{12}$.

The intake of micronutrients such as selenium $(45 \mu \mathrm{g} /$ day), vitamin A (500mg/day), vitamin C (60mg/day), vitamin $\mathrm{E}(12 \mathrm{mg} /$ day), folate $(320 \mu \mathrm{g} / \mathrm{dia})$ and fiber $(20-35$ $\mathrm{mg} / \mathrm{dia}$ ) were analyzed according to the Dietary Reference Intake recommendations ${ }^{10}$. Saturated fatty acids: $<7 \%$, polyunsaturated: $<10 \%$, monounsaturated: $<20 \%$ are suggested by the Food and Nutrition Board of the Institute of Medicine, using the Estimated Average Requirements ${ }^{14}$. Dietary intake of cases and controls was verified.

Volunteers were also asked if they followed any sort of dietary recommendation, the type of fat that was most frequently used (subcategorized by vegetable and animal fat), the consumption of chicken/fish skin and/or excessive meat fat, the use of sweetener and the additional salt added to meals.

The database was prepared in Excel 2010 and statistical analysis was performed using SPSS Statistics software version 22.0 and Epinfo 7.0. Evaluation of data collected from dietary recalls was conducted on the Avanutri ${ }^{\circledast}$ software (Três Rios, Brazil).

Once the energy intake could influence the results of the analysis, all the evaluated nutrients were submitted to the energetic variation correction according to the WILLETT, HOWE, KUSHI residual method ${ }^{15}$.

Descriptive results were presented with mean and 
standard deviation or median (interquartile range), according to the presence or absence of a normal distribution, respectively, according to the Kolmogorov-Smirnov test.

Subsequently, a One-Way ANOVA test was performed to correct the micronutrient intake values, in order to determine the intra and interindividual variabilities and the total variance of the distribution. Other tests such as Student's t-test and Mann-Whitney/Wilcoxon Two-Sample were used to evaluate differences between groups, considering the level of significance of $\alpha<5.0 \%(p<0.05)$.

Odds Ratios were calculated in order to evaluate the odds of certain variables related to food consumption, energy intake, macro and micronutrients among participants with breast cancer (case) versus healthy controls, with a 95\% confidence interval (Cl). For all association analyses, the level of significance considered was $\alpha<5.0$ ( $p<0.05$ ).

\section{RESULTS}

From the 160 patients evaluated, we observed that the mean age of cases $(52.89 \pm 11.65$ years $)$ and controls $(52.26 \pm 11.88$ years) was similar $(p=0.71)$, ranging from 31 to 86 years (cases) and from 30 to 87 years (controls), according the previous sample homogenization. The mean years of study was $7.9 \pm 4.3$ years (cases) and $11.9 \pm 4.6$ years (controls), ranging from 0 to 17 years (cases) and from 1 to 25 years (controls), with significant difference between groups $(p=0.01)$. The information on race, marital status and residence is presented in table 1.

The results concerning dietary habits (Table 2) show that $77.5 \%(n=124)$ of the volunteers did not followed any sort of dietary recommendation, in which the majority were breast cancer patients $(p=0.004)$. By analyzing macro and micronutrient intake, we observed that the consumption of energy, vitamin $\mathrm{A}$, vitamin $\mathrm{C}$, vitamin $\mathrm{E}$, fiber, selenium and folic acid were below the recommended level for both groups (Table 3).

Regarding the fat/oils used for cooking, fat from vegetable sources (soybean oil) was the most consumed $(73.7 \%)$ in both groups. We observed that $39.4 \%(n=63)$ reported consumption of fish skin. The consumption of fat visible on meat was $33.3 \%(n=53)$. Daily use of sweetener was reported by $18.7 \%(n=30)$ while the habit of adding additional salt to meals was reported by $50 \%(n=80)$ of the respondents (Table 2).

We observed that the mean of total and saturated lipids consumption was significantly higher in the control group, but it did not exceed the recommended maximum values10 and the OR did not meet statistical significance (Table 4). Both groups presented vitamin A intake below the recommended level, however the case group presented even lower consumption, differing significantly from the control group.

The results showed that the majority of women with breast cancer did not follow any sort of dietary recommendations. The odds of not following dietary recommendations were 3.37 times greater among those with breast cancer compared to those without breast cancer. The odds of consumption of chicken skin or fish skin and meat fat, as well as the use of sweetener and additional salt were not significantly higher among breast cancer patients compared to controls (Table 4).

Regarding to the consumption of total lipids, although the value of $p$ was less than 0.05 , the confidence interval included the value $1.0(\mathrm{OR}=0.508,95 \% \mathrm{Cl}=0.24-1.06$, $\mathrm{p}<0.05)$. On the other hand, breast cancer participants had greater odds of having insufficient vitamin $\mathrm{A}$ intake compared to controls $(\mathrm{OR}=2.46,95 \% \mathrm{Cl}=1.19-5.05, \mathrm{p}<0.01)$ (Table 5).

Table 1. Sociodemographic variables investigated from women with and without breast cancer participating in the study. Goiânia-GO, 2014 - 2017 (n= 160).

\begin{tabular}{|c|c|c|c|c|c|c|c|}
\hline \multirow[t]{2}{*}{ Variables } & \multicolumn{2}{|c|}{$\begin{array}{l}\text { Case } \\
(n=80)\end{array}$} & \multicolumn{2}{|c|}{$\begin{array}{c}\text { Control } \\
(n=80)\end{array}$} & \multicolumn{2}{|c|}{$\begin{array}{c}\text { Total } \\
(n=160)\end{array}$} & \multirow[t]{2}{*}{$\mathbf{p}^{*}$} \\
\hline & $\mathbf{N}$ & $\%$ & $\mathbf{N}$ & $\%$ & $\mathbf{N}$ & $\%$ & \\
\hline \multicolumn{8}{|l|}{ Race } \\
\hline White & 28 & 35,0 & 35 & 43,7 & 43 & 26,9 & 0,33 \\
\hline Black/Brown & 52 & 65,0 & 45 & 56,3 & 30 & 60,6 & \\
\hline \multicolumn{8}{|l|}{ Marital Status } \\
\hline With partner & 46 & 57,5 & 48 & 60,0 & 94 & 58,7 & 0,87 \\
\hline Without partner & 34 & 42,5 & 32 & 40,0 & 66 & 41,2 & \\
\hline \multicolumn{8}{|l|}{ Residence } \\
\hline Goiânia & 42 & 52,5 & 73 & 91,3 & 115 & 71,9 & 0,01 \\
\hline Others & 38 & 47,5 & 07 & 8,7 & 45 & 28,1 & \\
\hline
\end{tabular}

*Chi-square. 
Table 2. Dietary habits of women, with and without breast cancer participating in the study. Goiânia GO, 2014 - 2017 ( $n=160$ ).

\begin{tabular}{|c|c|c|c|c|c|c|c|}
\hline \multirow[t]{2}{*}{ Variables } & \multicolumn{2}{|c|}{$\begin{array}{c}\text { Case } \\
(n=80)\end{array}$} & \multicolumn{2}{|c|}{$\begin{array}{r}\text { Control } \\
(n=80)\end{array}$} & \multicolumn{2}{|c|}{$\begin{array}{l}\text { Total } \\
(n=160)\end{array}$} & \multirow{2}{*}{$\mathbf{p}^{*}$} \\
\hline & $\mathbf{N}$ & $\%$ & $\mathbf{N}$ & $\%$ & $\mathbf{N}$ & $\%$ & \\
\hline \multicolumn{8}{|l|}{ Follow dietary recommendation } \\
\hline No & 70 & 87,5 & 54 & 67,5 & 124 & 77,5 & 0,004 \\
\hline Yes & 10 & 12,5 & 26 & 32,5 & 36 & 22,5 & \\
\hline \multicolumn{8}{|l|}{ Type of fat } \\
\hline Fat from animal source & 7 & 8,8 & 6 & 7,5 & 13 & 8,1 & 0,75 \\
\hline Fat from vegetable source & 73 & 91,2 & 74 & 92,5 & 147 & 91,9 & \\
\hline \multicolumn{8}{|c|}{ Consumption of Chicken/Fish skin } \\
\hline Yes & 33 & 41,2 & 30 & 37,5 & 63 & 39,4 & 0,75 \\
\hline No & 47 & 58,8 & 50 & 62,5 & 97 & 60,6 & \\
\hline \multicolumn{8}{|l|}{ Consumption of meat fat } \\
\hline Yes & 25 & 31,6 & 28 & 35,0 & 53 & 33,3 & 0,74 \\
\hline No & 54 & 68,4 & 52 & 65,0 & 106 & 66,7 & \\
\hline \multicolumn{8}{|l|}{ Daily use of sweetener } \\
\hline Yes & 13 & 16,2 & 17 & 21,2 & 30 & 18,7 & 0,54 \\
\hline No & 67 & 83,8 & 63 & 78,8 & 130 & 81,3 & \\
\hline \multicolumn{8}{|l|}{ Addition of salt } \\
\hline Yes & 39 & 48,8 & 41 & 51,2 & 80 & 50,0 & 1,00 \\
\hline No & 39 & 48,8 & 41 & 51,2 & 80 & 50,0 & \\
\hline
\end{tabular}

*Chi-square.

Table 3. Comparison of macro and micronutrient mean intake of women with and without breast cancer participating in the study. Goiânia-GO, 2014-2017 ( $n=480$ food recalls).

\begin{tabular}{|lccc|}
\hline Nutrient $^{1,2}$ & $\begin{array}{c}\text { Case } \\
(\mathbf{n = ~ 8 0 )}\end{array}$ & $\begin{array}{c}\text { Control } \\
(\mathbf{n = ~ 8 0 )}\end{array}$ & p \\
\hline Energy (kcal) & $1453 \pm 423,5$ & $1513 \pm 378,4$ & $0,351^{3}$ \\
Carbohydrates (g) & $211(192-225)$ & $206(189-221)$ & $0,279^{4}$ \\
Proteins (g) & $58,6(49,8-70,1)$ & $65,9(58,7-74,8)$ & $0,006^{4}$ \\
Lipids (g) & $38,9(33,4-46,8)$ & $45,9 \pm 8,97$ & $0,0001^{4}$ \\
Saturated fatty acids (g) & $7,9(5,2-11,4)$ & $10,2(8,25-13,2)$ & $0,0002^{4}$ \\
Polyunsaturated fatty acids (g) & $5,00(3,48-6,59)$ & $4,85(3,56-7,51)$ & $0,756^{4}$ \\
Monounsaturated fatty acids (g) & $10,0(5,98-13,5)$ & $8,63(6,65-11,9)$ & 0,626 \\
Fibers (g) & $15,3(11,1-19,1)$ & $13,7(10,9-13,7)$ & $0,286^{4}$ \\
Vitamin A ( $\mu$ gER) & $180(102-395)$ & $319(192-627)$ & $0,0003^{4}$ \\
Vitamin C (mg) & $46,4(19,5-117,6)$ & $48,5(27,5-105)$ & $0,718^{4}$ \\
Vitamin E (mg) & $6,86(4,61-10,9)$ & $6,96(4,73-10,4)$ & $0,889^{4}$ \\
Selenium ( $\mu \mathrm{g})$ & $35,8(26,5-50,6)$ & $44,8(35,4-68,5)$ & $0,104^{4}$ \\
Folic acid $(\mu \mathrm{g})$ & $71,0(49,6-105,9)$ & $85,2(63,7-116,8)$ & $0,132^{4}$ \\
\hline
\end{tabular}

${ }^{1}$ Data presented as mean \pm standard deviation or median (interquartile range). ${ }^{2}$ The nutrients were adjusted by energy according to the residual method (Willett, Howe and Kushi, 1997). ${ }^{3}$ Student's t test for dependent samples. ${ }^{4}$ Wilcoxon test. 
Table 4. Odds ratio $(\mathrm{OR})$ for food consumption variables among breast cancer cases versus controls. Goiânia-GO, 2014-2017 ( $n=480$ food recalls).

\begin{tabular}{|c|c|c|c|c|c|c|c|}
\hline \multirow[t]{2}{*}{ Variables } & \multicolumn{2}{|c|}{ Case $(n=80)$} & \multicolumn{2}{|c|}{ Control $(n=80)$} & \multirow[t]{2}{*}{ OR } & \multirow[t]{2}{*}{$95 \% \mathrm{Cl}$} & \multirow[t]{2}{*}{$\mathbf{p}^{*}$} \\
\hline & $\mathbf{N}$ & $\%$ & $\mathbf{N}$ & $\%$ & & & \\
\hline Follow dietary recommendation (no) & 70 & 87,5 & 54 & 67,5 & 3,37 & $1,50-7,58$ & 0,004 \\
\hline Consumption of fat/oils from animal source (yes) & 7 & 8,8 & 6 & 7,5 & 1,18 & $0,38-3,69$ & 0,39 \\
\hline Consumption of chicken/fish skin (yes) & 33 & 41,3 & 47 & 58,8 & 1,17 & $0,62-2,21$ & 0,63 \\
\hline Consumption of meat apparent fat (yes) & 25 & 31,7 & 28 & 35,0 & 0,86 & $0,44-1,66$ & 0,65 \\
\hline Daily use of sweetener (yes) & 13 & 15,3 & 17 & 21,3 & 0,72 & $0,32-1,60$ & 0,42 \\
\hline Addition of salt (yes) & 39 & 48,8 & 39 & 48,8 & 1,00 & $0,54-1,86$ & 1,00 \\
\hline
\end{tabular}

*Chi-square.

Table 5. Odds ratio (OR) for average energy, macro and micronutrients intake among breast cancer cases and controls. Goiânia-GO, 2014-2017 ( $n=480$ food recalls).

\begin{tabular}{|c|c|c|c|c|c|c|c|}
\hline \multirow[t]{2}{*}{ Variables } & \multicolumn{2}{|c|}{$\begin{array}{c}\text { Case } \\
(n=80)\end{array}$} & \multicolumn{2}{|c|}{$\begin{array}{l}\text { Control } \\
(n=80)\end{array}$} & \multirow[t]{2}{*}{ OR } & \multirow[t]{2}{*}{$95 \% \mathrm{Cl}$} & \multirow[t]{2}{*}{$\mathbf{p}^{*}$} \\
\hline & $\mathbf{N}$ & $\%$ & $\mathbf{N}$ & $\%$ & & & \\
\hline Energy intake (IE) (>1750Kcal) & 19 & 23,8 & 61 & 76,3 & 1,350 & $0,63-2,89$ & 0,220 \\
\hline Carbohydrate (g) (>75\%) & 4 & 5,00 & 0 & 0,0 & - & - & 0,060 \\
\hline Proteins (g) (>15\%) & 53 & 66,3 & 62 & 77,5 & 0,570 & $0,28-1,15$ & 0,059 \\
\hline Lipids (g) $(>30 \%)$ & 15 & 18,8 & 25 & 31,3 & 0,508 & $0,24-1,06$ & 0,036 \\
\hline Saturated fatty acids (g) (>7\% da IE) & 21 & 26,3 & 29 & 36,3 & 0,626 & $0,32-1,23$ & 0,089 \\
\hline Polyunsaturated fatty acids (g) & 0 & 0 & 1 & 1,2 & 0,000 & - & 0,500 \\
\hline Monounsaturated fatty acids (g) & 80 & 100 & 80 & 100 & - & - & 1,00 \\
\hline Fibers $(<20 \mathrm{~g})$ & 62 & 77,5 & 70 & 87,5 & 0,492 & $0,21-1,15$ & 0,051 \\
\hline Vitamin A $(<500 \mathrm{mg} / \mathrm{dia})$ & 65 & 81,3 & 51 & 63,8 & 2,464 & $1,19-5,05$ & 0,007 \\
\hline Vitamin C (<60 mg) & 46 & 57,5 & 47 & 58,8 & 0,950 & $0,51-1,78$ & 0,437 \\
\hline Vitamin E (<12 mg) & 63 & 78,8 & 65 & 81,3 & 0,855 & $0,39-1,86$ & 0,349 \\
\hline Selenium $(<45 \mu g)$ & 52 & 65,0 & 49 & 61,3 & 1,175 & $0,62-2,24$ & 0,314 \\
\hline Folic acid $(<320 \mu \mathrm{g})$ & 80 & 100 & 80 & 100,0 & - & - & 1,00 \\
\hline
\end{tabular}

*Chi-square.

\section{DISCUSSION}

The key findings of the study revealed that women with breast cancer were 3.37 and 2.46 times more likely to not follow dietary recommendations and consume less than $500 \mathrm{mg}$ per day of vitamin A compared to women without breast cancer whom attended a federal public referral center in the Central-West region of Brazil.

As it is a multifactorial disease, breast cancer is associated not only with biological factors, but also with environmental and social aspects ${ }^{3}$. In the present study, when performing the sociodemographic characterization, the groups were similar in relation to race and marital status. However, they differed significantly in respect to residence. This result may be justified by the fact that CORA-HC-UFG is a reference center for the diagnosis and treatment of breast cancer in the central-western state and region, making it possible to access patients from surrounding municipalities.

We observed that more than three-quarters of the women interviewed did not follow food recommendations (such as decreasing salt, sugar, fat and/or pasta intake), which was also observed in every Brazilian region according to the last Family Budget Survey carried out in the country ${ }^{16}$. Additionally, there was a greater likelihood of these patterns among women with breast cancer, possibly due to high consumption of pro-inflammatory foods, which are highly processed, rich in sugar, sodium and unhealthy fats and 
with a reduced consumption of anti-inflammatory foods and antioxidants such as fruits, vegetables and nuts ${ }^{17}$.

The process of industrialization and urbanization has possibly influenced food changes in the Brazilian population, contributing to increases of nearly $6.0 \%$ in ultra-processed food consumption in the country ${ }^{15,17}$. This is a contributing factor for some types of cancer, including breast cancer, because they create a favorable environment for breast tumor progression due to metabolic and hormonal dysregulation ${ }^{19}$. Therefore, adequate consumption of lipids concomitant with energy adequacy and increased consumption of fruits, vegetables and legumes may be crucial for reducing the risk for breast cancer as well as other chronic non-communicable diseases, which is in line with our results.

A review study suggests that the consumption of monounsaturated fatty acids (from olive oil and other sources) may modestly reduce the risk of breast neoplasia ${ }^{13}$. Another article, that considered prospective studies about the US population, showed an association between increased omega-3/omega- 6 consumption and a reduced risk of developing breast cancer, suggesting their role in disease prevention ${ }^{20}$.

Dietary fiber may play a protective role against breast cancer because of its ability to reduce estrogen concentrations circulating in the bloodstream. In this way, they promote the inhibition of intestinal reabsorption of estrogen excreted in bile, in addition to favoring the increase of their fecal excretion ${ }^{21}$. Therefore, the adequate consumption of dietary fiber has been investigated as a possible protective factor against breast cancer ${ }^{21}$. In the present study, however, low fiber intake among breast cancer participants versus controls was borderline not significant. It should be noted that the majority of women $(75.0 \%)$ with and without cancer had low consumption of dietary fiber, representing a concern.

Data from the Family Budget survey (2008-2009) shows that Brazilians have a low consumption of fiber ${ }^{18}$ reiterating the importance of promoting a diet rich in sources of fiber, such as fruits and vegetables.

A cohort study, using a convenience sample of 11,576 participants with breast cancer, found an inverse association of total dietary fiber intake and the disease incidence. Results were obtained using the Risk Ratio measured from the fifth to the first quintile of fiber consumption ( $R R=0.95,95 \%$ $\mathrm{Cl}=0.89-1.01, \mathrm{p}=0.03)$, concluding that diets rich in fibers, is associated with a modest risk reduction ${ }^{22}$.

Regarding micronutrients, we found that only insufficient consumption of vitamin A was higher in the group with breast cancer compared to controls. Vitamin A plays an important role in the protection of cell membranes against the action of free radicals and reactive species, in the control of cell differentiation, proliferation and apoptosis, and may act to inhibit malignant neoplasms ${ }^{8}$.

Vitamin A and its derivatives are part of a group of liposoluble compounds that play an important role in several biological processes due to their ability to promote adequate embryonic development and participate in metabolic processes and cell growth and differentiation until adulthood ${ }^{23}$. This micronutrient has been shown to play a protective role in the development of breast cancer ${ }^{24}$.

A critical literature review of the recently published literature has evaluated studies published over the past 15 years and has suggested that vitamin A consumption (retinol, B-carotene, and its analogues) may play a role in inhibiting carcinogenesis, concluding that deficiency of this micronutrient may have the inverse effect in patients with breast cancer ${ }^{25}$.

A meta-analysis aimed to investigate the association between the development of breast cancer and total vitamin A intake compared the highest and lowest intake of the vitamin, $10000 \mathrm{IU} /$ day and $3000 \mathrm{IU} /$ day, respectively. When grouping 51 studies, they observed a significant reduction of $17 \%(\mathrm{HR}($ grouped $)=0.83,95 \% \mathrm{Cl}=0.78-0.88, \mathrm{p}<0.01)$. In addition, they compared total retinol intake, considering the highest value approximately $6000 \mathrm{mg} /$ day and the lowest intake around $1000 \mathrm{mg} /$ day. They analyzed 24 studies and found a $6 \%$ reduction in the risk of developing breast cancer $(\mathrm{HR}$ grouped $)=0.94,95 \% \mathrm{Cl}=0.89-0.99, \mathrm{p}=0.01)^{26}$.

Similar results to the present study were reported in a case-control study, conducted among Asian women with and without breast cancer. The authors found that the low plasma concentration, therefore low vitamin A intake, was twice as likely among the cases compared to controls (OR= $2.05,95 \% \mathrm{Cl}=0.19-4.10, \mathrm{p}<0.05)^{27}$.

It is important to highlight the relevance of this research due to the lack of studies explore dietary intake of macro and micronutrients among breast cancer patients compared to controls, especially in the Brazilian population. In addition, the results obtained can be used to carry out actions to prevent illness and promote health, and contribute to the reduction of risks to breast cancer regarding to the diet. These actions are foreseen and can be strengthened by the Strategic Action Plan to Tackle Noncommunicable Diseases (NCD) in Brazil, 2011-2022, of the Ministry of Health ${ }^{18}$.

However, the study presents limitations, such as the convenience sample. In addition, the use of $24 \mathrm{~h}$ dietary recall is based on the self-reported description and depends on the interviewee's memory and may not represent the food consumed reliably. Specifically, the consumption of foods popularly known as less healthy may be underestimated, while those considered healthy can be overestimated ${ }^{28}$.

\section{CONCLUSION}

The results of this study suggest that women with breast cancer may be less likely to follow dietary guidelines and more likely to have insufficient vitamin A intake compared to healthy controls.

\section{REFERENCES}

1. Brazil. Ministry of Health. Brazilian National Cancer Institute José Alencar Gomes da Silva. Coordination of Prevention and Surveillance. Estimate/2018 - Cancer Incidence in Brazil/ Coordination of Prevention and Surveillance. Rio de Janeiro, 
2017, p. 128

2. Bray F, Ferlay J, Soerjomataram I, Siegel RL, Torre $L A$, Jemal A. Global cancer statistics 2018: GLOBOCAN estimates of incidence and mortality worldwide for 36 cancers in 185 countries. CA Cancer J Clin 2018; 68(6): 394-424.

3. Colditz, GA, Bohlke, K. Priorities for the primary prevention of breast cancer. CA Cancer J Clin 2014; 64(3): 186-194.

4. Kushi LH, Doyle C, McCullough M, Rock CL, Demark Wahnefried W, Bandera EV, American Cancer Society 2010 Nutrition and Physical Activity Guidelines Advisory Committee. American Cancer Society Guidelines on nutrition and physical activity for cancer prevention: reducing the risk of cancer with healthy food choices and physical activity. CA Cancer I Clin 2012; 62(1): 30-67.

5. Rossi RE, Pericleous M, Mandair D, Whyand T, Caplin ME. The role of dietary factors in prevention and progression of breast cancer. Anticancer Res 2014; 34: 6861-6875.

6. Kerlikowske K, Gard CC, Tice JA, Ziv E, Cummings SR, Miglioretti DL. Risk factors that increase risk of estrogen receptor-positive and-negative breast cancer. I Natl Cancer Inst 2017; 109(5): 1-9.

7. Bao PP, Shu, XO, Zheng Y, Cai H, Ruan ZX, Gu K, Gao WT, Zheng W, Lu W., Fruit, Vegetable, and Animal Food Intake and Breast Cancer Risk by Hormone Receptor Status. Nutr Cancer 2012; 64(6): 806-819.

8. Dos Santos HS, de Souza Cruz WM. The Antioxidant Vitamin Nutritional Therapy and the Chemotherapy Treatment in Oncology. Rev Bras Cancerol 2001; 47(3): 303-308.

9. Aune D, Chan DSM, Greenwood DC, Vieira AR, Navarro Rosenblatt DA, Vieira $R$ et al. Dietary fiber and breast cancer risk: a systematic review and meta-analysis of prospective studies. Ann Oncol 2012; 23(6): 1394-1402.

10. Romieu II, Amadou A, Chajes V. The role of diet, physical activity, body fatness, and breastfeeding in breast cancer in young women: epidemiological evidence. Rev Invest Clin 2017; 69(4): 193-203.

11. Fisberg RM, Martini $L A$, Slater $B$. Methods of food inquiry. In: Fisberg RM, Slater B, Marchioni DML, Martini LA. Food inquiry: methods and scientific bases. Barueri, SP, Manole, 2005, p. 1-29.

12. World Health Organization/Food and Agriculture Organization. Diet, nutrition and the prevention of chronic diseases: report of a joint WHO/FAO expert consultation, Geneva, 2002, $p$. 149.

13. Cattafesta M, Siqueira JH, Podestá OPG, Podestá JRV, Salaroli LB. Food Intake in Patients with Breast Cancer Accompanied in Specialized Oncology Center in Grande Vitória/ES-Brazil, Rev Bras Oncol Clin 2014; 10(38): 124-131.

14. Institute of Medicine. DRI's - Dietary Reference Intakes for energy, carbohydrate, fiber, fat, fatty acids, cholesterol, protein, and amino acids. National Academy Press 2005.

15. Willett WC, Howe GR, Kushi LH. Adjustment for total energy intake in epidemiologic studies. Am J Clin Nutr 1997; 65(4):
1220S-1228S.

16. Brazil. Brazilian Institute of Geography and Statistics. National Household Budget Survey 2008-2009. Rio de Janeiro, 2011, p. 150.

17. Cibeira GH, Guaragna RM. Lipid: risk factor and breast cancer prevention. Rev Nutr 2006; 19(1): 65-75.

18. Brazil. Ministry of Health. Health Surveillance Secretariat. Health Situation Analysis Department. Strategic action plan to tackle noncommunicable diseases (NCD) in Brazil 20112022 / Ministry of Health. Health Surveillance Secretariat. Health Situation Analysis Department - Brasilia 2011; 160.

19. Gunter MJ, Xie X, Xue X, Kabat GC, Rohan TE, WassertheilSmoller S,et al. Breast cancer risk in metabolically healthy but overweight postmenopausal women. Cancer Res 2015; 75(2): 270-274.

20. Yang B, Ren XL, Fu YQ, Gao JL, Li D. Ratio of n-3/n-6 PUFAs and risk of breast cancer: a meta-analysis of 274135 adult females from 11 independent prospective studies. BMC Cancer 2014; 14(1): 105.

21. Kaaks R, Berrino F, Key T, Rinaldi S, Dossus L, Biessy C, et al. Serum sex steroids in premenopausal women and breast cancer risk within the European Prospective Investigation into Cancer and Nutrition (EPIC). I Natl Cancer Inst 2005; 97(10): 755-765.

22. Ferrari $P$, Rinaldi $S$, Jenab $M$, Lukanova $A$, Olsen $A$, Tjønneland, et al. Dietary fiber intake and risk of hormonal receptor-defined breast cancer in the European Prospective Investigation into Cancer and Nutrition study. Am J Clin Nutr 2013; 97(2): 344-353.

23. Rochette-Egly C. Retinoic acid signaling and mouse embryonic stem cell differentiation: Cross talk between genomic and non-genomic effects of RA. Biochim Biophys Acta 2015; 1851(1): 66-75.

24. Fulan H, Changxing J, Baina $W Y$, Wencui Z, Chunqing $L$, Fan $W$, et al. Retinol, vitamins $A, C$, and $E$ and breast cancer risk: a meta-analysis and meta-regression. Cancer Causes Control 2011; 22(10): 1383.

25. Limon-Miro AT, Lopez-Teros V, Astiazaran-Garcia $H$. Dietary Guidelines for Breast Cancer Patients: A Critical Review. Adv Nutr 2017; 8(4): 613-623.

26. Assi N, Moskal A, Slimani N, Viallon V, Chajes V, Freisling $H$, et al. A treelet transform analysis to relate nutrient patterns to the risk of hormonal receptor-defined breast cancer in the European Prospective Investigation into Cancer and Nutrition (EPIC). Public Health Nutr 2016; 19(2): 242-254.

27. Suzana S, Normah H, Fatimah A, Fadilah RN, Rohi GA, Amin l, et al. Antioxidant intake and status, and oxidative stress in relation to breast cancer risk: a case-control study. Asian Pacific J Cancer Prev 2008; 9(2): 343-350.

28. Fisberg RM, Marchioni DML, Colucci ACA. Assessment of food consumption and nutrient intake in clinical practice. Arch Brasileiros Endocrinol Metabol 2009; 53(5): 617-624. 